\title{
DEVELOPMENT OF A NEW TYPE OF MILK-CONTAINING ICE-CREAM ENRICHED WITH BLENDED OIL
}

\author{
I. Ustymenko, G. Polischuk
}

National University of Food Technologies

\begin{tabular}{l}
\multicolumn{1}{c}{ Key words: } \\
Food emulsion \\
Dairy fat substitutes \\
Blended oil \\
Ice cream \\
Milk containing product \\
\hline
\end{tabular}

Article history:

Received 13.11.2018

Received in revised form

29.11.2018

Accepted 18.12.2018

\section{Corresponding author:}

I. Ustymenko

E-mail:

ustymenko_ihor@ukr.net

\begin{abstract}
The article substantiates scientifically the recipe composition of a new type of ice cream with a combined composition of raw materials. As a fat-containing component, it is suggested to use food emulsions based on the dairy fat substitutes and blended oil.

The purpose of the study is to determine the possible degree of replacement of dairy fat substitutes for blended oil at different fatty properties of the finished product.

To solve the problem for use in the composition of ice cream combined warehouse, food emulsions with $40 \%$ fat content based on the dairy fat substitutes "Violia-molzhir 3" as a product of perestrification, which does not contain in its composition harmful to the body trans-isomers of fatty acids and based on the blended oil (sunflower oil + olive oil at a ratio of 80:20). The composition and technology of food emulsions developed by authors make it possible to obtain a fatty normalizing component of the emulsion type with an average size of fat cells not more than 2 microns of high stickiness. The regularities of the influence of the degree of replacement of dairy fat substitutes on the loss of resistance, dentin resistance, the average size of air bubbles and the organoleptic parameters of experimental samples of ice cream combined fatty with 3.5 to $15 \%$ of fat.

A rational stage of substituting milk fat for oil was blended into food emulsions for: ice cream with $3.5 \%-30 \%$; ice cream with $10 \%-20 \%$; ice cream with $15 \%-15 \%$. New types of ice cream of combined content, made in accordance with scientifically-based recommendations, are characterized by high quality. On the basis of the obtained results, the basic recipes of ice cream with the combined composition of raw materials are developed.
\end{abstract}

DOI: $10.24263 / 2225-2924-2018-24-6-30$

\section{РОЗРОБКА НОВОГО ВИДУ МОЛОКОВМІСНОГО МОРОЗИВА, ЗБАГАЧЕНОГО КУПАЖОВАНОЮ ОЛІЕЮ}

\author{
І.М. Устименко, Г.С. Поліщук \\ Національний університет харчових технологій
}

У статті науково обгрунтовано рещептурний склад нового виду морозива з комбінованим складом сировини. Як жировмісний компонент запропоно- 
вано використовувати харчові емульсї̈ на основі замінника молочного жсиу та олї купажованої.

Метою дослідження є визначення можливого ступеня заміни замінника молочного жиру на купажовану олію за різної жирності готового продукту.

Для вирішення поставленого завдання для застосування у складі морозива комбінованого складу обрано харчові емульсії жирністю 40\%, що стабілізовані емульгувальним комплексом (казеїнат натрію-емульгатор «Твердий-2»), на основі замінника молочного жиру «Віолія-молюир 3» як продукту переетерифікації, щзо не містить у своєму складі икідливих для організму трансізомерів жирних кислот, i на основі олї купажованої (соняшникова олія+ +оливкова олія за співвідношення 80:20). Розроблені авторами склад $і$ технологія харчових емульсій дають змогу отримувати жсировий нормалізаційний компонент емульсійного типу з середнім розміром жирових кульок не більше 2 мкм високої стіййості. Вивчено закономірності впливу ступеня заміни замінника молочного жиру на збитість, опір таненню, середній розмір повітряних бульбашок та органолептичні показники дослідних зразків морозива комбінованого складу жирністю від 3,5 до 15\%.

Встановлено раціональний ступінь заміни замінника молочного жиру на олію купажовану у складі харчових емульсій для: морозива молочного жирністю 3,5\% - 30\%; морозива вершкового жирністю 10\% - 20\%; пломбіру жирністю 15\% - 15\%. Нові види морозива комбінованого складу, виготовлені відповідно до науково-обгрунтованих рекомендацій, відрізняються високими показниками якостіі. На основі отриманих результатів розроблено базові рецептури морозива з комбінованим складом сировини.

Ключові слова: харчова емульсія, замінник молочного жиру, купажована олія, морозиво, продукт молоковмісний.

Постановка проблеми. В умовах економічної кризи зниження собівартості харчових продуктів є одним 3 найвагоміших чинників впливу на вибір підприємствами асортименту, технологій і технічного забезпечення процесу виробництва. Тому в молочній галузі стрімко розвиваються технології молоковмісних продуктів. Але, зазвичай, як немолочні жирові компоненти у складі таких продуктів використовують доволі дешеві тропічні олії та замінники молочного жиру. Останні є продуктами гідрогенізації олій, що містять небезпечні для здоров'я транс-ізомери жирних кислот і характеризуються невисокою харчовою цінністю [1; 2].

У той же час сучасна структура харчування населення України характеризується такими порушеннями харчового статусу:

- дефіцитом поліненасичених жирних кислот (ПНЖК) на фоні надлишкового споживання насичених жирів за недостатнього споживання рослинних олій;

- дефіцитом білків тваринного походження.

Доведено, що використання жирів рослинного походження у складі молоковмісних продуктів підвищує їхню харчову цінність [3-5]. Тому вітчизняних споживачів слід більше орієнтувати на підвищення частки у раціоні хар- 
чування олій і жирів рослинного походження через їхні фізіологічні переваги і нижчу вартість порівняно з тваринними жирами.

Практика показала, що виробництво морозива 3 комбінованим складом сировини дає змогу розширити асортимент продукції, збалансувати іiі споживчу якість за вмістом ПНЖК, подовжити терміни зберігання (токофероли та фосфоліпіди, що містяться в оліях інгібують процеси окиснення жирів $\mathrm{i}$ попереджають появу в продукті пероксидів та вільних жирнокислотних радикалів за рахунок нижчої вартості жирового компоненту рослинного походження [6;7].

Перевагами застосування рослинних олій та продуктів їх переробки у складі морозива $є$ можливість поєднання фракцій жирів різного хімічного складу i властивостей для досягнення найвищої якості морозива, а також можливість виготовляти морозиво зі стабільними при зберіганні показниками якості, нейтральним смаком і запахом за відсутності шкідливих для організму людини речовин (холестерину, транс-ізомерів жирних кислот (ТІЖК) та ін.) [8].

В Україні близько $60 \%$ від обсягів виробництва морозива виготовляють із застосуванням рослинних олій і продуктів їх переробки з частковою або повною заміною молочного жиру. Для жирів, температура плавлення (Тпл) яких наближена до Тпл молочного жиру, заміна останнього може бути повною [9].

$\mathrm{y}$ той же час деякі олії можуть надавати морозиву специфічний присмак $\mathrm{i}$ запах. Немолочні жири та продукти їх переробки, зокрема ЗМЖ, також не забезпечують організм людини ПНЖК омега-3 і омега-6 за рекомендованого співвідношення та у достатній кількості. У виробництві морозива комбінованого широко застосовують тропічні олії та жири, які характеризуються гарними пластичними властивостями й органолептичними показниками, але можуть бути джерелом шкідливих для здоров'я транс-ізомерів жирних кислот. $\mathrm{У}$ той же час, готовий продукт має незбалансований жирнокислотний склад $[10 ; 11]$.

Відповідно до рекомендацій Типової технологічної інструкції ТТІ 317486581-2007 до ДСТУ 4733:2007, 4734:2007, 4735:2007 з виробництва морозива, у тому числі комбінованого складу, під час технологічного процесу спочатку отримують грубодисперсні емульсії внесенням жирів рослинного походження до складу сумішей за постійного перемішування. В подальшому їх гомогенізують за режимами залежно від обраної схеми диспергування (одноступенева або двоступенева гомогенізація).

$\mathrm{У}$ той же час жирова фаза морозива повинна ефективно кристалізуватися за низьких температур під час фризерування і подальшого загартування, що обумовлює формування кремоподібної структурованої консистенції та високий опір таненню. Тому надлишковий вміст рідких олій у морозиві знижує споживчі властивості морозива та погіршує його структуру.

Для забезпечення часткового агрегування жирових кульок у процесі фризерування, що $є$ бажаним ефектом для досягнення сухості поверхні готового продукту, дуже важливим $є$ проміжне співвідношення між рідкою і твердою жировою фазами під час фризерування. Якщо у жировій фазі суміші для виробництва морозива дуже багато рідкого жиру, то він у процесі фризерування переміщується на поверхню повітряних кульок і руйнує їх. 
R.T. Marshall (стверджує, що вміст кристалічного жиру за температури 4$5^{\circ} \mathrm{C}$ має становити від половини до 2/3 загального вмісту жиру [12].

Оскільки кристалізація жиру відбувається в три етапи (переохолодження жиру, утворення зародків кристалів, зростання кристалів), для жирової фази, диспергованої у вигляді емульсії, кожна краплинка жиру має кристалізуватися незалежно від інших. Тому у жировій кульці обов'язково мають міститися центри кристалізації, що не завжди забезпечується і призводить до надлишкового переохолодження жировмісних сумішей та відповідних перевитрат холоду. Для запобігання цьому процесу рідкі олії гідрогенізують, що призводить до внесення до складу морозива разом із гідрогенізованим жиром транс-ізомерів жирних кислот. Але за умови застосування високоплавких замінників молочного жиру цілком можливо їх частково замінювати на біологічно повноцінні і дешеві рідкі олії вітчизняного виробництва.

Метою дослідження $\epsilon$ визначення раціонального ступеня заміни жиру на купажовану рідку олію за різної жирності готового продукту.

Матеріали і методи. Для вирішення поставленого завдання як жирову фазу для морозива комбінованого складу обрано розроблені авторами харчові емульсії жирністю 40\%, стабілізовані емульгувальним комплексом «казеїнат натрію + емульгатор Т-2». Застосування нормалізаційних харчових емульсій дасть змогу виключити 3 технологічної схеми технологічну операцію «гомогенізація суміші» та скоротити тривалість технологічного процесу [13].

Як жирову фазу емульсій використовували замінник молочного жиру (ЗМЖ) «Віолія-молжир 3» як продукт перетерифікації, що не містить у своєму складі ТІЖК, та олію купажовану, збалансовану за жирнокислотним складом (соняшникова олія+оливкова олія за співвідношення 80:20).

Для складання дослідних зразків використовували сировину згідно з ДСТУ 4733:2007 «Морозиво молочне, вершкове, пломбір. Загальні технічні вимоги.

У дослідних зразках морозива визначали опір таненню, збитість і середній розмір повітряних бульбашок у морозиві за ступеня заміни ЗМЖ на купажовану олію у межах від 10 до 35\%. Обраний діапазон ступеня заміни твердоподібного жиру на рідкі олії включав рекомендовану кількість - від 20 до 30\% [14].

Жирність зразків морозива комбінованого складу складала 3,5, 10 та $15 \%$, що відповідає жирності морозива класичних видів. За контроль обрано морозиво з вказаним вмістом жиру на основі ЗМЖ «Віолія-молжир 3».

М'яке морозиво 3 комбінованим складом сировини виготовляли із застосуванням фризера для виробництва морозива марки ФПМ-3,5/380-50 «Ельбрус400» ТУ У.14086152.081-97. Виробник - АТ «РОСС», м. Харків, Україна.

Мікроструктурний аналіз зразків проводили 3 використанням світлового мікроскопу XS-2610 та цифрової фотокамери Canon S3. Розміри жирових кульок визначали мікроскопічним методом за збільшення не менше ніж у $400 \ldots 600$ разів (10x40 або $15 \times 40)$ з подальшим математичним обробленням результатів вимірювання [15].

Збитість м'якого морозива визначали ваговим методом [16].

Опір таненню морозива визначали за часом витікання зі зразка морозива діаметром 35 мм та висотою 50 мм $10 \mathrm{~cm}^{3}$ рідкої суміші (у хв), що утворювалася внаслідок розплавлення морозива у термостаті при температурі $25^{\circ} \mathrm{C}$ [17]. 
Органолептичну оцінку зразків морозива проводили за 10-бальною системою 3 прийнятим розподілом значимості його окремих показників: смак, запах та аромат -6 балів, структура та консистенція - 3 балів, колір і зовнішній вигляд - 1 бал.

Результати і обговорення. Результати дослідження впливу ступеня заміни ЗМЖ на опір таненню, збитості, середній розмір повітряних бульбашок наведено у табл. $1-3$. Темним тлом у таблицях виокремлені значення, які не відповідають існуючим вимогам до фізико-хімічних показників морозива гарантованої якості, відповідно до яких опір таненню має бути не нижчим за 41 хв для морозива всіх видів, середній розмір повітряних бульбашок має бути не більшим за 60 мкм, а збитість повинна бути не нижчою за $60 \%$ для жирності 3,5\% і не нижчою за 80\% — для морозива 10\% і 15\% жирності [17].

Таблиця 1. Опір таненню (хв) зразків морозива з комбінованим складом сировини з різним ступенем заміни ЗМЖ на олію купажовану $(P \geq 0,95 ; n=3)$

\begin{tabular}{|c|c|c|c|c|c|c|c|}
\hline \multirow{2}{*}{$\begin{array}{c}\text { Досліджувані } \\
\text { зразки }\end{array}$} & \multicolumn{7}{|c|}{$\begin{array}{c}\text { Ступінь заміни ЗМЖ на олію купажовану, } \\
\text { \% від загального вмісту жиру, \% }\end{array}$} \\
\cline { 2 - 8 } & 0 & 10 & 15 & 20 & 25 & 30 & 35 \\
\hline $\begin{array}{c}\text { Морозиво 3 } \\
\text { м.ч.ж. 3,5 \% }\end{array}$ & $43,9 \pm 1,7$ & $43,6 \pm 1,1$ & $42,6 \pm 2,0$ & $42,0 \pm 1,3$ & $41,5 \pm 0,9$ & $41,4 \pm 1,5$ & $34,2 \pm 1,6$ \\
\hline $\begin{array}{c}\text { Морозиво 3 } \\
\text { м.ч.ж. 10 \% }\end{array}$ & $49,4 \pm 2,0$ & $48,1 \pm 1,5$ & $44,2 \pm 1,4$ & $41,8 \pm 1,7$ & $40,0 \pm 1,4$ & $35,1 \pm 0,9$ & $30,1 \pm 1,1$ \\
\hline $\begin{array}{c}\text { Морозиво 3 } \\
\text { м.ч.ж. 15 \% }\end{array}$ & $53,0 \pm 2,5$ & $49,6 \pm 2,0$ & $45,1 \pm 2,1$ & $40,7 \pm 1,5$ & $38,2 \pm 1,1$ & $34,9 \pm 1,0$ & $32,0 \pm 1,2$ \\
\hline
\end{tabular}

Таблиия 2. Збитість (\%) зразків морозива 3 комбінованим складом сировини 3 різним ступенем заміни ЗМЖ на олію купажовану $(P \geq 0,95 ; n=3)$

\begin{tabular}{|c|c|c|c|c|c|c|c|}
\hline \multirow{2}{*}{$\begin{array}{c}\text { Досліджувані } \\
\text { зразки }\end{array}$} & \multicolumn{7}{|c|}{ Ступінь заміни ЗМЖ на олію купажовану, } \\
\cline { 2 - 7 } & 0 & 10 & 15 & 20 & 25 & 30 & 35 \\
\hline $\begin{array}{c}\text { Морозиво 3 } \\
\text { м.ч.ж. 3,5 \% }\end{array}$ & $85,3 \pm 3,0$ & $82,8 \pm 2,1$ & $80,2 \pm 2,0$ & $75,9 \pm 3,5$ & $61,3 \pm 2,7$ & $58,2 \pm 1,7$ & $55,2 \pm 2,2$ \\
\hline $\begin{array}{c}\text { Морозиво 3 } \\
\text { м.ч.ж. 10 \% }\end{array}$ & $89,1 \pm 3,6$ & $85,8 \pm 3,1$ & $83,8 \pm 2,0$ & $80,4 \pm 3,3$ & $74,8 \pm 1,9$ & $69,9 \pm 2,4$ & $57,0 \pm 1,4$ \\
\hline $\begin{array}{c}\text { Морозиво 3 } \\
\text { м.ч.ж. 15\% \% }\end{array}$ & $96,4 \pm 4,2$ & $90,9 \pm 3,9$ & $85,1 \pm 2,7$ & $79,6 \pm 2,5$ & $76,0 \pm 3,0$ & $70,8 \pm 3,1$ & $61,0 \pm 2,4$ \\
\hline
\end{tabular}

Таблиия 3. Середній розмір повітряних бульбашок (мкм) зразків морозива 3 комбінованим складом сировини 3 різним ступенем заміни ЗМЖ на олію купажовану $(P \geq 0,95 ; n=3)$

\begin{tabular}{|c|c|c|c|c|c|c|c|}
\hline \multirow{2}{*}{$\begin{array}{c}\text { Досліджувані } \\
\text { зразки }\end{array}$} & \multicolumn{6}{|c|}{ Ступінь заміни 3МЖ на олію купажовану, \% від загального вмісту жиру, } \\
\cline { 2 - 7 } & 0 & 10 & 15 & 20 & 25 & 30 & 35 \\
\hline $\begin{array}{c}\text { Морозиво 3 } \\
\text { м.ч.ж. 3,5 \% }\end{array}$ & $38,1 \pm 1,1$ & $40,8 \pm 1,6$ & $48,2 \pm 1,5$ & $50,0 \pm 2,1$ & $55,3 \pm 2,4$ & $59,2 \pm 2,0$ & $75,0 \pm 2,9$ \\
\hline $\begin{array}{c}\text { Морозиво 3 } \\
\text { м.ч.ж. 10 \% }\end{array}$ & $35,1 \pm 1,0$ & $38,8 \pm 1,4$ & $42,8 \pm 1,6$ & $45,4 \pm 1,2$ & $55,4 \pm 1,9$ & $62,9 \pm 2,8$ & $67,0 \pm 2,1$ \\
\hline $\begin{array}{l}\text { Морозиво 3 } \\
\text { м.ч.ж. 15\% }\end{array}$ & $34,4 \pm 1,2$ & $40,9 \pm 1,2$ & $55,1 \pm 1,9$ & $61,5 \pm 2,4$ & $66,0 \pm 2,2$ & $71,8 \pm 3,0$ & $72,1 \pm 2,4$ \\
\hline
\end{tabular}


Мікроструктуру морозива на прикладі систем зі ступенем заміни ЗМЖ на купажовану олію 15, 25 і 35\%, порівняно з морозивом комбінованого складу жирністю 3,5\% (контроль 1), 10\% (контроль 2) і 15\% (контроль 3), наведено на рис. 1.

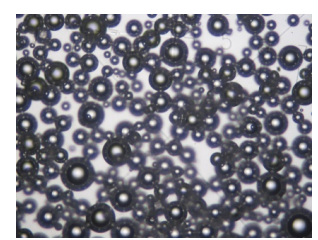

Контроль 1 Морозиво з м.ч.ж. 3,5 \% (молочного типу)

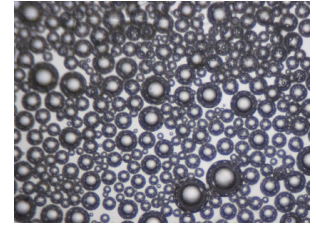

$15 \%$ заміни

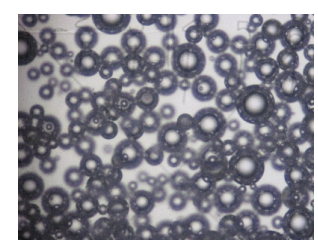

$25 \%$ заміни

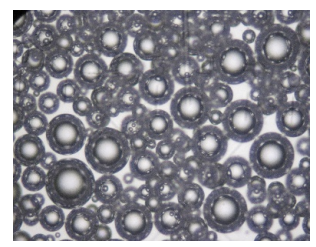

$35 \%$ заміни

Морозиво з м.ч.ж. 10 \% (вершкового типу)

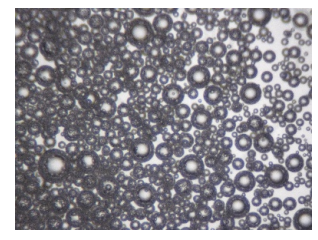

Контроль 2

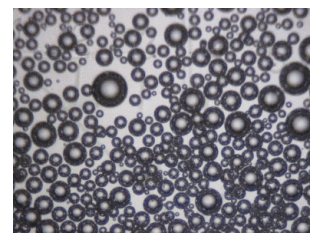

$15 \%$ заміни

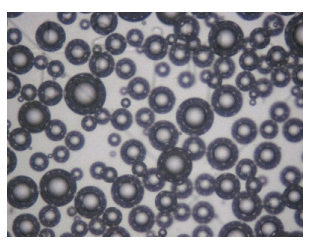

$25 \%$ заміни

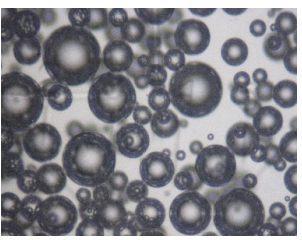

$35 \%$ заміни

Морозиво $з$ м.ч.ж. 15 \% (пломбірного типу)

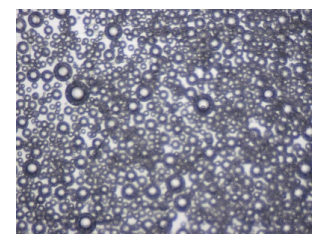

Контроль 3

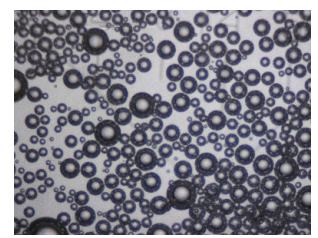

$15 \%$ заміни

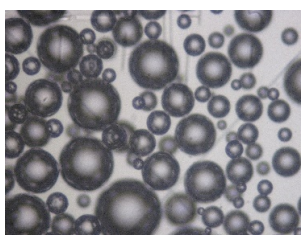

$25 \%$ заміни

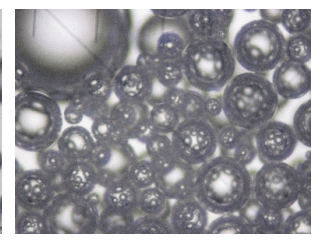

$35 \%$ заміни

Рис. 1. Мікроструктура зразків морозива з різним складом жирової фази за збільшення 10x15

3 рис. 1 видно, що, незважаючи на початковий, значно вищий ступінь дисперсності повітряної фази у морозиві з масовою часткою жиру $15 \%$, саме для цього виду спостерігається найбільший негативний вплив рідких олій на мікроструктуру готового продукту. Цей ефект можна пояснити більшим вмістом рідких олій у готовому продукті, які спричиняють коалесценцію (злиття) повітряних бульбашок 3 подальшим руйнуванням.

Отже, відповідно до результатів дослідження, наведених у табл. $1-3$ та на рис. 1 , досягнення рекомендованих значень опору таненню, дисперсності повітряної фази і збитості задовольняє заміна до 30\% ЗМЖ на рідкі олії для морозива жирністю $3,5 \%$, до 20\% — для морозива жирністю $10 \%$ і до $15 \%$ для морозива жирністю $15 \%$.

На наступному етапі наукового дослідження проведено органолептичну оцінку дослідних зразків морозива 3 комбінованим складом сировини з різним ступенем заміни ЗМЖ на олію купажовану. Органолептичні показники морозива 3 комбінованим складом сировини та їх бальну оцінку представлено у табл. 4. 
Таблиия 4. Органолептичні показники морозива з комбінованим складом сировини 3 різним ступенем заміни ЗМЖ на олію купажовану

\begin{tabular}{|c|c|c|c|c|c|c|c|}
\hline \multirow{2}{*}{$\begin{array}{c}\text { Масова частка } \\
\text { жиру у зразку, \% }\end{array}$} & \multicolumn{7}{|c|}{$\begin{array}{c}\text { Ступінь заміни ЗМЖ на олію купажовану, } \\
\text { \% від загального вмісту жиру }\end{array}$} \\
\hline & 0 & 10 & 15 & 20 & 25 & 30 & 35 \\
\hline \multicolumn{8}{|c|}{ Смак і запах (максимальна кількість 6 балів) } \\
\hline 3,5 & \multicolumn{7}{|c|}{$\begin{array}{c}\text { Характерні для морозива цієї групи, приємні, } \\
\text { без сторонніх присмаків і запахів }\end{array}$} \\
\hline Кількість балів & \multicolumn{7}{|c|}{6} \\
\hline 10,0 & \multicolumn{6}{|c|}{$\begin{array}{c}\text { Характерні для морозива цієї групи, приємні, без } \\
\text { сторонніх присмаків і запахів }\end{array}$} & $\begin{array}{l}\text { Легкий при- } \\
\text { смак купажу }\end{array}$ \\
\hline Кількість балів & \multicolumn{6}{|c|}{6} & 5 \\
\hline 15,0 & \multicolumn{3}{|c|}{$\begin{array}{c}\text { Характерні для морозива цієї } \\
\text { групи, приємні, без сторонніх } \\
\text { присмаків і запахів }\end{array}$} & \multicolumn{3}{|c|}{ Легкий присмак купажу } & $\begin{array}{c}\text { Виражений } \\
\text { присмак } \\
\text { купажу }\end{array}$ \\
\hline Кількість балів & \multicolumn{3}{|c|}{6} & \multicolumn{3}{|c|}{5} & 3 \\
\hline \multicolumn{8}{|c|}{ Структура і консистенція (масимальна кількість 3 бали) } \\
\hline 3,5 & \multicolumn{3}{|c|}{$\begin{array}{c}\text { Однорідна, } \\
\text { слабо сніжиста консистенція. }\end{array}$} & \multicolumn{3}{|c|}{$\begin{array}{l}\text { Однорідна, помірно } \\
\text { густа }\end{array}$} & $\begin{array}{l}\text { Однорідна, } \\
\text { дещо рідка }\end{array}$ \\
\hline Кількість балів & \multicolumn{6}{|c|}{2,5} & 2 \\
\hline 10,0 & \multicolumn{2}{|c|}{$\begin{array}{c}\text { Однорідна, } \\
\text { кремоподібна }\end{array}$} & \multicolumn{2}{|c|}{$\begin{array}{c}\text { Однорідна, } \\
\text { достатньо густа }\end{array}$} & \multicolumn{3}{|c|}{ Однорідна, дещо рідка } \\
\hline Кількість балів & \multicolumn{2}{|c|}{3} & \multicolumn{2}{|c|}{2,5} & \multicolumn{3}{|c|}{2} \\
\hline 15,0 & \multicolumn{3}{|c|}{ Однорідна, достатньо густа } & \multicolumn{2}{|c|}{$\begin{array}{c}\text { Однорідна, дещо } \\
\text { рідка }\end{array}$} & \multicolumn{2}{|c|}{$\begin{array}{l}\text { Неоднорідна, } \\
\text { нестійка }\end{array}$} \\
\hline Кількість балів & \multicolumn{3}{|c|}{3} & \multicolumn{2}{|c|}{2,5} & & 2 \\
\hline \multicolumn{8}{|c|}{ Колір, зовнішній вигляд (масимальна кількість 1 бал) } \\
\hline 3,5 & \multicolumn{3}{|c|}{$\begin{array}{c}\text { Біло-молочний, рівномірний за } \\
\text { всією масою, поверхня суха }\end{array}$} & \multicolumn{4}{|c|}{$\begin{array}{c}\text { Біло-молочний, рівномірний за всією } \\
\text { масою, поверхня помірно блискуча }\end{array}$} \\
\hline Кількість балів & \multicolumn{3}{|c|}{1} & \multicolumn{4}{|c|}{0,5} \\
\hline 10,0 & \multicolumn{4}{|c|}{$\begin{array}{c}\text { Біло-кремовий, рівномірний за всією } \\
\text { масою, поверхня суха }\end{array}$} & \multicolumn{3}{|c|}{$\begin{array}{l}\text { Біло-кремовий, } 3 \text { жовтуватим } \\
\text { відтінком, поверхня блискуча }\end{array}$} \\
\hline Кількість балів & \multicolumn{4}{|c|}{1} & & 0 , & \\
\hline 15,0 & $\begin{array}{l}\text { Біло-кр } \\
\text { всією }\end{array}$ & $\begin{array}{l}\text { рівн } \\
\text { пове }\end{array}$ & оний за & $\begin{array}{r}\text { Кремовс } \\
\text { всією ма }\end{array}$ & $\begin{array}{l}\text { жовтува } \\
\text { ою, пове }\end{array}$ & $\begin{array}{l}\text { ий, рі } \\
\text { ихя д }\end{array}$ & $\begin{array}{l}\text { зномірний за } \\
\text { уже блискуча }\end{array}$ \\
\hline Кількість балів & & 1 & & & & 5 & \\
\hline
\end{tabular}

Результати органолептичної оцінки зразків морозива 3 комбінованим складом сировини та різним ступенем заміни ЗМЖ підтвердили встановлений за фізико-хімічними показниками раціональний вміст рідких олій для морозива 3 різним вмістом жиру. На основі отриманих результатів розроблено базові рецептури морозива з комбінованим складом сировини з використанням жирового концентрату на основі ЗМЖ та олій купажованої.

Перспективи подальших досліджень полягають у вивченні можливостей введення до базових рецептур натуральних гомогенних і гетерогенних смакоароматичних інгредієнтів, що дасть змогу розширити асортиментний ряд біологічно повноцінної продукції.

\section{Висновки}

Науково підтверджено можливість збагачення морозива 3 комбінованим складом сировини біологічно повноцінною купажованою олією у вигляді хар- 
чової емульсії, стабілізованої комплексом емульгаторів «казеїнат натрію+емульгатор Т-2».

Експериментально обгрунтовано максимально можливий ступінь заміни замінника молочного жиру на олію купажовану у складі морозива жирністю від 3,5 до 15,0\% та встановлено зворотну залежність між раціональним ступенем заміни замінника молочного жиру на купажовану рідку олію (від 15 до $30 \%$ ) та жирністю морозива, що забезпечує високу збитість морозива та стійкість утвореної пінної структури.

На основі отриманих результатів розроблено базові рецептури нового виду морозива з комбінованим складом сировини.

\section{Лiтература}

1. Шубравська О.В., Сокольська Т.В. Розвиток ринку молока і молочної продукції: світові тенденції і вітчизняні перспективи. Економіка і прогнозування. 2010. № 2. С. $80-93$.

2. Грек О.В., Лихолат О.С. Аспекти ресурсозбереження в молочній галузі. Молокопереробка. 2012. № 5(80). C. 20-23.

3. Harris W.S. The omega-3 indexas a risk factor for coronary heart disease. Am. J. Clin. Nutr. 2008. № 87. P. 1997-2002.

4. Корецький В.Л., Орлова Н.М. До проблеми безпеки харчування та моніторингу якості життя населення України. Проблеми харчування. 2006. № 1. С. $42-44$.

5. Gibson G.R., Williams C.M. Functional food: concept to product. CRC Press, Woodhead Publishing Limited, Cambridge, England. 2000. 356 p.

6. Грек О.В., Осьмак Т.Г. Інноваційні розробки в молочній галузі. Молочная индустрия. 2013. № 2. С. $42-43$.

7. Патент України на корисну модель № 24569, А23G9/00. Морозиво комбіноване / Л.М. Хомічак, Т.А. Скорченко, Г.Є. Поліщук, Т.Г. Федченко. и 200700239; заявл. 10.01.2007; опубл. 10.07.2007, Бюл. № 10.

8. Двинский Б.М. Пищевые ингридиенты, добавки и пряности. Молочная промышленность. 2008. № 3. С. $85-89$.

9. Granger C. Leger A., Barey P., Langendorff V., Cansell M. Influence of formulation on the structural networks in ice cream. Int. Dairy J. 2005. No. 15. C. 255-262.

10. Hu F.B., Stampfer M.J., Manson J.E., Rimm E., Colditz G.A., Rosner B.A., Hennekens C.H. \& Willett W.C. Dietary fat intake and the risk of coronary heart disease in women. New England Journal of Medicine. 1997. 337(2). P. 1491-1502.

11. Патент 92092 UA, МПК A23G 9/04 (2009) A23G 9/32 (2009) Склад морозива 3 комбінованим складом сировини / Поліщук Г.С., Кочубей-Литвиненко О.В., Згурський А.В.; заявник Національний університет харчових технологій. № а 200901157; заявл. 13.02.2009; опубл. 27.09.2010, Бюл. № 18

12. Marshall R.T., Goff H.D., Hartel R.W. Ice Cream, 6th Edn. New York: Kluwer Academic. ISBN 0-306-47700-9. 2003. 366 p.

13. Научное обоснование состава эмульсий для нормализации белково-жировых продуктов / Г. Поліщук, Г. Сімахіна, І. Устименко та ін. Maisto chemija ir technologija. 2016. № 1. С. 45-55.

14. Clarke C. The Science of Ice Cream. The Royal Society of Chemistry: Cambridge, UK, 2004. $241 \mathrm{p}$.

15. Vega C., Dalgleish D.G., Goff H.D. Effect of $\kappa$-Carrageenan Addition to Dairy Emulsions Containing Sodium Caseinate and Locust Bean Gum. Food Hydrocolloids. 2005. Vol. 19, No. 2. P. 187-195.

16. Маршал Р.Т., Гофф Г.Д. Мороженое и замороженные десерты; перев. с англ. под ред. В.И. Василевського. СПб.: Професия, 2005. 376 с.

17. Оленев Ю.А, Творогова А.А., Казакова Н.В., Соловьева Л.Н. Справочник по производству мороженого. Москва: ДеЛи Принт, 2004. 798 с. 